\title{
Experimentally induced chocolate craving leads to an attentional bias in increased distraction but not in speeded detection
}

Citation for published version (APA):

Smeets, E., Roefs, A. J., \& Jansen, A. T. M. (2009). Experimentally induced chocolate craving leads to an attentional bias in increased distraction but not in speeded detection. Appetite, (53), 370-375. https://doi.org/10.1016/j.appet.2009.07.020

Document status and date:

Published: 01/01/2009

DOI:

10.1016/j.appet.2009.07.020

Document Version:

Publisher's PDF, also known as Version of record

Document license:

Taverne

Please check the document version of this publication:

- A submitted manuscript is the version of the article upon submission and before peer-review. There can be important differences between the submitted version and the official published version of record.

People interested in the research are advised to contact the author for the final version of the publication, or visit the DOI to the publisher's website.

- The final author version and the galley proof are versions of the publication after peer review.

- The final published version features the final layout of the paper including the volume, issue and page numbers.

Link to publication

\footnotetext{
General rights rights.

- You may freely distribute the URL identifying the publication in the public portal. please follow below link for the End User Agreement:

www.umlib.nl/taverne-license

Take down policy

If you believe that this document breaches copyright please contact us at:

repository@maastrichtuniversity.nl

providing details and we will investigate your claim.
}

Copyright and moral rights for the publications made accessible in the public portal are retained by the authors and/or other copyright owners and it is a condition of accessing publications that users recognise and abide by the legal requirements associated with these

- Users may download and print one copy of any publication from the public portal for the purpose of private study or research.

- You may not further distribute the material or use it for any profit-making activity or commercial gain

If the publication is distributed under the terms of Article $25 \mathrm{fa}$ of the Dutch Copyright Act, indicated by the "Taverne" license above, 
Research report

\title{
Experimentally induced chocolate craving leads to an attentional bias in increased distraction but not in speeded detection
}

\author{
Elke Smeets *, Anne Roefs, Anita Jansen \\ Department of Clinical Psychological Science, Maastricht University, Maastricht, The Netherlands
}

\section{A R T I C L E I N F O}

\section{Article history:}

Received 19 January 2009

Received in revised form 5 July 2009

Accepted 22 July 2009

\section{Keywords:}

Attentional bias

Craving

Chocoholics

Speeded detection

Increased distraction

\begin{abstract}
A B S T R A C T
In the present study, the causal influence of chocolate craving on attentional bias for chocolate-related information was examined by experimentally inducing chocolate craving in a sample of high trait chocolate cravers vs. low trait chocolate cravers. A sample of 35 high trait chocoholics and 33 low trait chocolate cravers were randomly assigned to either the exposure condition in which craving was manipulated or the non-exposure condition. To measure attentional bias, a pictorial version of the visual search paradigm [Smeets, E., Roefs, A., van Furth, E., \& Jansen, A. (2008). Attentional bias for body and food in eating disorders: increased distraction, speeded detection, or both? Behaviour Research and Therapy, 46, 229-238] was used, assessing two components: distraction and detection. It was found that experimentally induced chocolate craving led to increased distraction by chocolate pictures in the high trait chocolate cravers, in comparison to the low trait chocolate cravers. Moreover, this measure of distraction correlated strongly with self-reported craving, but only in the chocoholics and in the exposure condition. In the non-exposure condition, high trait chocolate cravers showed speeded detection of chocolate pictures relative to non-chocoholics, but this component did not correlate with self-reported craving. It is concluded that experimentally induced craving for chocolate causes a bias in, specifically the increased distraction component of attention in high trait chocolate cravers.
\end{abstract}

(c) 2009 Elsevier Ltd. All rights reserved.
Over the past decades, ample research has demonstrated attentional biases for craving-related stimuli (e.g., alcohol, drugs, and cigarettes) in individuals for whom these stimuli are of particular concern. An attentional bias is defined as the tendency to selectively attend to personally relevant information over neutral information (Mathews \& MacLeod, 2005). Using the emotional Stroop paradigm, research from the field of addiction has consistently shown that alcoholics (Bauer \& Cox, 1998; Cox, Hogan, Kristian, \& Race, 2002; Cox, Yeates, \& Regan, 1999; Stormark, Laberg, Nordby, \& Hugdahl, 2000), smokers (Gross, Jarvik, \& Rosenblatt, 1993; Walters \& Feyerabend, 2000), and drug addicts (Franken, Kroon, Wiers, \& Jansen, 2000) show increased interference when naming the colour of craving-related stimuli as compared to neutral stimuli. In addition, findings from studies using the dot-probe paradigm also support the presence of attentional biases in these individuals (Ehrman et al., 2002; Lubman, Peters, Mogg, Bradley, \& Deakin, 2000).

In explaining the occurrence of these attentional biases, a link has been proposed between selective attentional processing and

\footnotetext{
* Corresponding author at: Faculty of Psychology and Neuroscience, Department of Clinical Psychological Science (FdP-UNS 40), Maastricht University, P.O. Box 616, 6200 MD Maastricht, The Netherlands.

E-mail address: elke.smeets@maastrichtuniversity.nl (E. Smeets).
}

craving (Franken, 2003; Robinson \& Berridge, 1993). Indeed, a substantial number of studies have found significant correlations between attentional bias for craving-related stimuli and levels of subjective craving (e.g., Field et al., 2007; Field, Mogg, \& Bradley, 2005; Franken et al., 2000; Rosse et al., 1997; Rosse, Miller, Hess, Alim, \& Deutch, 1993). Other studies suggest that this relationship only holds true for a specific component of the attentional bias. In general, two subcomponents of attention have been distinguished by attentional bias researchers using paradigms like the dot-probe paradigm (i.e., Macleod, Mathews, \& Tata, 1986; Mogg, Field, \& Bradley, 2005), the exogenous cueing paradigm (Fox, Russo, Bowles, \& Dutton, 2001) and the odd-one-out visual search paradigm (Hansen \& Hansen, 1988; Rinck, Reinicke, Ellwart, Heuer, \& Becker, 2005). The first subcomponent is involved in the early attentional processing of information whereas the second subcomponent is specifically involved in late attentional processing. Depending on the attentional bias paradigm that is used, the first subcomponent is referred to as increased initial orienting (i.e., Mogg et al., 2005), engagement (i.e., Fox et al., 2001), or speeded detection (i.e., Rinck et al., 2005) while the second subcomponent is referred to as greater maintained attention (i.e., Mogg et al., 2005), slowed disengagement (i.e., Fox et al., 2001), or increased distraction (i.e., Rinck et al., 2005). Using eye-tracking, Mogg et al. (2005) showed that higher levels of craving are correlated specifically with greater maintained attention for smoking cues 
in smokers. Likewise, Field, Mogg, Zetteler, and Bradley (2004) only found a correlation between craving and the attentional bias for alcohol cues in the maintenance component of attention.

Apart from addiction-related stimuli, attentional biases have also been reported for food-related stimuli. More specifically, these biases have been demonstrated in restrained eaters (Francis, Stewart, \& Hounsell, 1997), dieters (Cooper \& Fairburn, 1992), eating disorder individuals (for reviews see: Faunce, 2002; Lee \& Shafran, 2004), people who are food deprived (Placanica, Faunce, \& Soames Job, 2002), hungry (Mogg, Bradley, Hyare, \& Lee, 1998), or in people who have just finished an appetizer (Overduin, Jansen, \& Louwerse, 1995). In a recent study from our laboratory we used an odd-one-out variant of the visual search paradigm (Hansen \& Hansen, 1998; Rinck et al., 2005) to investigate two subcomponents of attention (i.e., speeded detection and increased distraction) that might underlie the attentional bias in eating disorder patients (Smeets, Roefs, van Furth, \& Jansen, 2008). Speeded detection refers to the faster detection of relevant stimuli in the environment, whereas increased distraction refers to the heightened distraction which can be brought about by these relevant stimuli. Results indicated that eating disorder patients showed evidence of increased distraction by food-related information, but not of the speeded detection of this kind of information (Smeets et al., 2008). In line with Mogg and colleagues (2005), we concluded that this increased distraction by food, might reflect a craving response. In other words, experiencing food cravings might have led eating disorder patients to be more distracted by foodrelated information while searching for neutral information. Nevertheless, as measuring or experimentally inducing craving was neither the goal of our study or of other previous studies, no conclusions can be drawn about the link between food cravings and the attentional bias for food. In this perspective, the purpose of the present study was to unravel the nature of this link in more detail in a non-clinical group of trait chocolate cravers experiencing intense and frequent cravings for chocolate (Benton, Greenfield, \& Morgan, 1998). Specifically our aim was to induce chocolate craving in samples of high and low trait chocolate cravers and to examine the direct impact of this manipulation on the attentional processing of chocolate-related pictures in a visual search paradigm. A pictorial chocolate variant of the visual search paradigm as used by Smeets et al. (2008) was developed. Participants were randomly assigned to one of two conditions: the exposure condition, in which chocolate craving was induced, or the non-exposure condition.

It was hypothesized that high trait chocolate cravers in the nonexposure condition would show speeded detection of chocolate pictures, in comparison to low trait chocolate cravers. Based on previous addiction studies in which a craving-related bias was specifically found in maintained attention, we expected our craving induction to cause an attentional bias effect in the distraction component (which may resemble maintained attention). In this line, it was hypothesized that the craving induction (i.e., exposure) would lead to increased distraction by chocolate pictures in trait chocolate cravers, in comparison to the low trait cravers and the non-exposure condition. Finally, self-reported craving was expected to correlate with the distraction component of the attentional bias

\section{Methods}

\section{Participants}

A total of 68 female undergraduate students were invited to participate in a study ostensibly investigating the relationship between perception and cognition. Inclusion criteria were either a high (highest $25 \%$ ) or a low (lowest $25 \%$ ) score on the chocolate craving subscale of the Attitudes to Chocolate Questionnaire (Benton et al., 1998) which was assessed 2 weeks before the experiment. Participants with a high score (i.e., a score above 10) on the chocolate craving subscale were classified as high trait chocolate cravers (henceforth called chocoholics), and participants with a low score (i.e., a score below -10) were classified as low trait chocolate cravers (henceforth called non-chocoholics). Both chocoholics $(n=35)$ and non-chocoholics $(n=33)$ were randomly assigned to either the exposure condition or the non-exposure condition. In total 18 chocoholics and 17 non-chocoholics were assigned to the exposure condition, and 17 chocoholics and 16 non-chocoholics were assigned to the non-exposure condition. All participants received course credits for their participation. The present study was approved by the local committee for research ethics.

\section{Materials}

Pictorial chocolate visual search task. Each trial started with a brief tone, after which the participant was shown a fixation cross for $500 \mathrm{~ms}$ in the middle of the computer screen. Then she was presented with a $5 \times 4$ matrix of 20 pictures and was instructed to indicate whether the matrix contained 20 pictures of the same category or whether it contained one picture from a different category (the odd-one-out). If the matrix contained an odd-oneout picture (henceforth called the target picture), she was instructed to press the right button of a response-box. If the matrix did not contain an odd-one-out picture, she was instructed to press the left button. Note that the counterbalancing of right and left button is not necessary as only the target present trials are relevant for testing our hypotheses. The matrix remained on screen until response or for a maximum of $20 \mathrm{~s}$ upon which the next trial began. The location of each picture in each matrix was chosen randomly for each trial and for each participant. However, the target picture never appeared directly above or below the location of the fixation cross in order to avoid facilitated detection. Participants were informed about the four categories stimuli could come from.

Pictorial stimuli from four categories were used: chocolate, candy, couches (neutral), and handbags (neutral). The function (i.e., target or distractor) of the neutral categories (couches and handbags) was counterbalanced over participants. Matrices on target present trials consisted of one chocolate-related picture among 19 couches/handbags, one candy-related picture among 19 couches/handbags, one handbag among 19 couches, one couch/ handbag among 19 chocolate-related pictures, one couch/handbag among 19 candy-related pictures, or of one couch among 19 handbags. Each of the six types of matrices was shown 19 times to each participant. Matrices on target absent trials consisted of 20 chocolate-related pictures, 20 candy-related pictures, 20 handbags, or of 20 couches. There were 114 target present trials, 40 target absent trials, and 12 practice trials. Trials with candy-related pictures were included as an additional control category to check whether the attentional bias effects are specific for chocolate or whether they generalize to other sweets.

In line with Smeets et al. (2008), the majority of the trials were target present trials because this type of trial is relevant for testing our hypotheses. Speeded detection of chocolate-related pictures is calculated by comparing response latencies to detect a chocolaterelated target picture vs. a neutral target picture (e.g., handbags) among neutral distractor pictures from one other category (e.g., couches). Increased distraction is calculated by comparing response latencies to detect a neutral target picture (e.g., a handbag) among chocolate-related pictures vs. neutral distractor pictures from one other category (e.g., couches).

The visual search task lasted approximately $20 \mathrm{~min}$, divided over two blocks of trials of $10 \mathrm{~min}$. The participant was given a brief 
break between blocks. The distance between the participant and the monitor was approximately $90 \mathrm{~cm}$. Within the frame of the matrix, pictures (height: $3.5 \mathrm{~cm}$ and width: $3.3 \mathrm{~cm}$ ) were horizontally separated by $6.76 \mathrm{~cm}$ and vertically by $6.5 \mathrm{~cm}$ (measured from the middle point of the stimulus picture). All pictures were displayed on a light-grey background on a 17-in. monitor with a resolution of $1280 \times 1024$ pixels.

Stimulus material. Out of a pool of 250 pictures taken from the Internet, 80 pictures were selected to create 20 -item lists for four categories (i.e., chocolate, candy, couches, and handbags). Pictures were matched as closely as possible on shape, colour and on the number of items present in a picture.

Manipulation check: state chocolate craving. State chocolate craving was assessed using a $100 \mathrm{~mm}$ Visual Analogue Scale (VAS) asking "how much do you crave chocolate at this very moment", ranging from 0 - "not at all" to 100 - "very much".

Trait chocolate craving. The chocolate craving subscale of the Attitudes to Chocolate Questionnaire (Benton et al., 1998) was used to select participants with a high and a low score on chocolate craving. This subscale consists of 16 statements about chocolate, such as, "My desire for chocolate often seems overpowering", "I eat chocolate to cheer me up when I'm down", and measures the amount of chocolate craving. Items are rated on a 7-point likert scale, ranging from $-3=$ strongly disagree to $3=$ strongly agree. Total scores range from -48 to 48 .

Restraint scale. The Restraint Scale (RS; Herman \& Polivy, 1980) is a 11-item scale, which measures the extent to which participants try to restrain their food intake. Higher scores reflect increased intention to restrain food intake.

\section{Manipulations}

To induce chocolate craving, participants in the exposure condition were exposed to 11 different kinds of chocolate on a table individually. Each participant was instructed to select the chocolates that appeared the most appealing to her, and was instructed to closely smell, touch, and feel these chocolates without eating them for $3 \mathrm{~min}$. After the first part of the visual search task, the participant was exposed to the chocolates again, but this time for $1 \mathrm{~min}$. The experimenter monitored whether participants complied with the instructions. Participants in the non-exposure condition were instructed to fill out a perception and concentration ranking questionnaire (i.e., control questionnaire) with items on artworks and colours. At the beginning of the experiment, each participant in the non-exposure condition was instructed to rank and give ratings for the artworks, while after the first part of the visual search task the participant was instructed to rank and give ratings for the colours.

\section{Procedure}

All participants were tested individually. Before entering the laboratory, participants signed the informed consent form and completed the state chocolate craving VAS (i.e., craving 1). Then participants were invited to the laboratory. Participants in the exposure condition were exposed to chocolates for $3 \mathrm{~min}$ while participants in the non-exposure condition completed the first part of the control questionnaire in which they had to rank twelve artworks from most to least beautiful. State chocolate craving was measured subsequently (i.e., craving 2). Thereafter, all participants took place behind the computer and completed the first part of the visual search task. The computer was located behind a big screen to prevent participants in the exposure condition from seeing the chocolates which were presented on a table at the other side of the screen. Upon finishing the first part of the task, participants rated their levels of state chocolate craving (i.e., craving 3). Then, participants in the exposure condition received an additional 1min lasting craving induction while participants in the nonexposure condition filled out a second part of the control questionnaire. State chocolate craving was measured (i.e., craving 4) and all participants completed the second part of the visual search task. Thereafter, state chocolate craving was measured one last time (i.e., craving 5) after which participants filled out a brief demographics questionnaire and the restraint scale. Finally, participants' height and weight were assessed.

\section{Results}

\section{Participant characteristics}

Analyses of variances were conducted to check for differences in age, BMI, restraint and trait chocolate craving between the groups. Four 2 (Group: chocoholics vs. non-chocoholics) $\times 2$ (Condition: exposure vs. non-exposure) ANOVAs with respectively age, BMI, Restraint, and trait chocolate craving as the dependent variables, revealed no significant Group $\times$ Condition interactions, all $F$ 's $<1.19$, all $p$ 's $>.28$, no significant main effects of Condition, all $F \mathrm{~s}<2.51$, all $p$ 's $>.12$, and no effects of group for age (chocoholics exposure condition: $M=21.17, S D=2.01$; chocoholics non-exposure condition: $M=21.06, S D=1.52$; non-chocoholics exposure condition: $M=21.41, S D=2.85$; non-chocoholics nonexposure condition: $M=21.19, S D=1.79$ ), BMI (chocoholics exposure condition: $M=21.93, S D=2.72$; chocoholics non-exposure condition: $M=21.58, S D=2.83$; non-chocoholics exposure condition: $M=21.79, S D=3.52$; non-chocoholics non-exposure condition: $M=19.95, S D=2.01$ ), and Restraint score (chocoholics exposure condition: $M=10.94, S D=4.02$; chocoholics non-exposure condition: $M=11.53, S D=3.43$; non-chocoholics exposure condition: $M=9.35, S D=4.46$; non-chocoholics non-exposure condition: $M=10.43, S D=4.38$ ), all $F$ s $<1.82$, all $p$ 's $>.18$. A significant main effect of Group was found for trait chocolate craving, $F(1,67)=7.44, p<.05$, chocoholics (chocoholics exposure condition: $M=17.12, S D=6.97$; chocoholics non-exposure condition: $M=18.35, S D=6.43$ ) scored significantly higher on trait chocolate craving than non-chocoholics (non-chocoholics exposure condition: $M=-28.45, S D=7.76$, non-chocoholics nonexposure condition: $M=-27.10, S D=6.74$.

\section{Manipulation check}

Two paired samples $t$-tests were conducted to investigate whether our manipulation was successful at increasing levels of state chocolate craving in the exposure condition. Analyses show that state chocolate craving levels at pre-measurement $(M=5.49$; $S D=2.65)$ increased significantly after the first $(M=6.60$, $S D=2.79), t(34)=3.47, p<.01$ and the second chocolate exposure $(M=6.42, S D=2.81), t(34)=3.23, p<.01$. Furthermore, an additional paired samples $t$-test showed that the level of chocolate craving after the first chocolate exposure was equal to the level of chocolate craving after the second chocolate exposure, $t(34)=1.06$, $p=.29$.

It can be concluded that our chocolate craving induction was successful at increasing levels of state chocolate craving in both chocoholics and non-chocoholics.

\section{Attentional bias scores}

We calculated bias scores (i.e., attentional bias difference scores) for both speeded detection and increased distraction. For investigating speeded detection effects, mean response latencies of trials in which a neutral target was presented among neutral distractors was subtracted from mean response latencies of trials 
in which a chocolate target was presented among neutral distractors. For investigating increased distraction effects, mean response latencies of trials in which a neutral target was presented among neutral distractors was subtracted from mean response latencies of trials in which a neutral target was presented among chocolate distractors.

Speeded detection. Bias scores were analyzed in a 2 (Condition: exposure vs. non-exposure) $\times 2$ (Group: chocoholics vs. nonchocoholics) ANOVA. Consistent with our expectations, a significant Condition $\times$ Group interaction was found, $F(1,64)=9.98$, $p<.01$. Furthermore, a trend significant main effect of Group, $F(1$, $64)=3.34, p=.07$, was found. The effect of Condition was not significant, $F(1,64)=0.86, p=.35$. See Fig. 1 a for means and SEs. Follow-up $t$-tests comparing exposure and non-exposure conditions separately for chocoholics and non-chocoholics were conducted. Chocoholics in the non-exposure condition were significantly faster at detecting a chocolate target than a neutral target in comparison to chocoholics in the exposure condition, $t(33)=2.93, p<.01$. For non-chocoholics, no effect of condition was found, $t(31)=1.56, p=.129$. In addition, $t$-tests comparing chocoholics and non-chocoholics within each condition were conducted. In the non-exposure condition, chocoholics were significantly faster at detecting chocolate targets than neutral targets in comparison to non-chocoholics, $t(31)=3.61, p<.01$. No difference between chocoholics and non-chocoholics was found in the exposure condition, $t(33)=0.93, n s$.
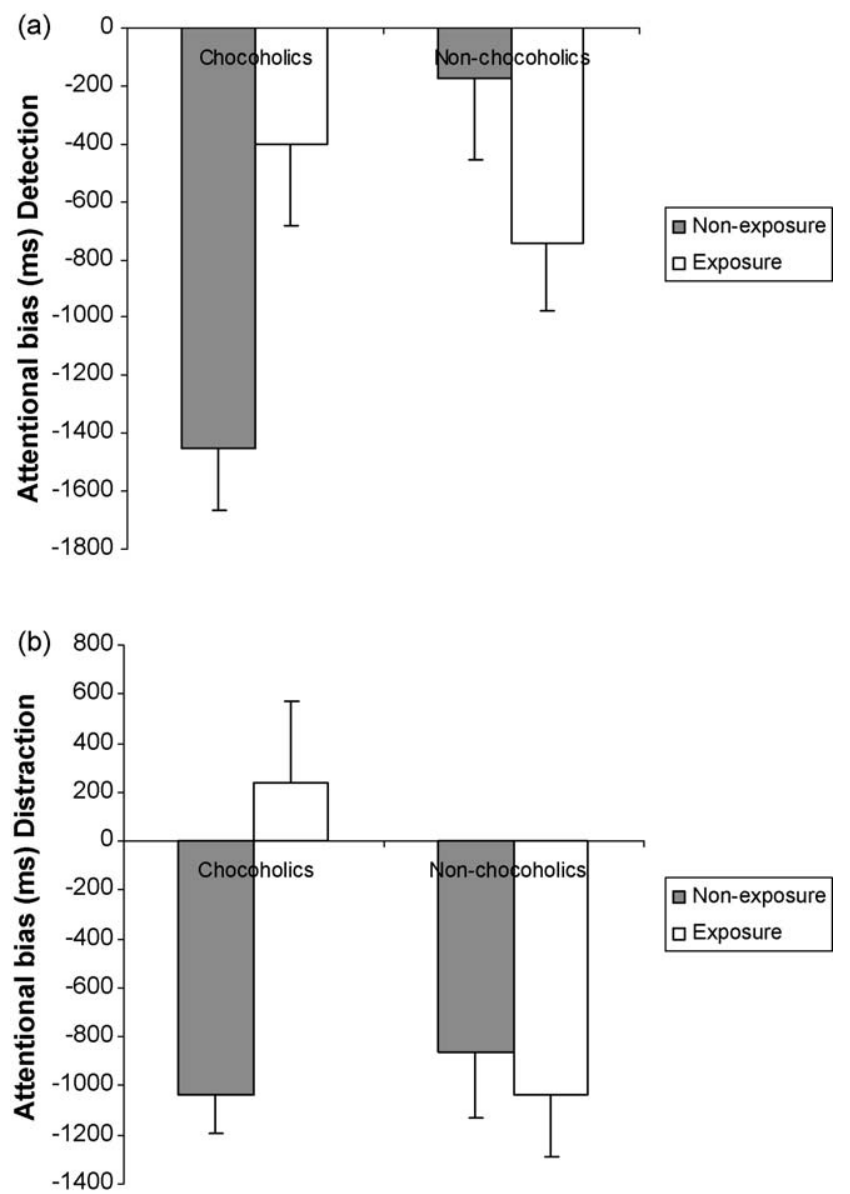

Fig. 1. (a) Mean bias scores of speeded detection ( $y$-axis) for chocoholics and nonchocoholics in the exposure and non-exposure condition ( $x$-axis). Error bars represent one standard error. (b) Mean bias scores of increased distraction ( $y$-axis) for chocoholics and non-chocoholics in the exposure and non-exposure condition $(x$-axis). Error bars represent one.
Taken together, chocoholics in the non-exposure condition showed speeded detection of chocolate targets, relative to chocoholics in the exposure condition and non-chocoholics in either the exposure or the non-exposure condition.

Increased distraction. Bias scores were analyzed in a 2 (Condition: exposure vs. non-exposure) $\times 2$ (Group: chocoholics vs. non-chocoholics) ANOVA. In accordance with our hypothesis, a significant Condition $\times$ Group interaction was found, $F(1$, $64)=7.62, p<.01$. Furthermore main effects of Condition, $F(1$, $64)=4.47, p<.05$, and Group, $F(1,64)=4.44, p<.05$ were found. See Fig. 1b for means and SEs. Follow-up t-tests comparing exposure and non-exposure conditions separately for chocoholics and non-chocoholics were conducted. In line with our expectations, chocoholics in the exposure condition showed significantly higher distraction bias scores in comparison to chocoholics in the non-exposure condition, $t(33)=3.44, p<.01$. In the non-chocoholics group, distraction bias scores did not differ between conditions, $t(31)=0.46$, $n s$. In addition, $t$-tests comparing chocoholics and non-chocoholics within each condition were conducted. Within the exposure condition, chocoholics showed significantly higher distraction bias scores than non-chocoholics, $t(33)=3.06$, $p<.01$. Within the non-exposure condition, distraction bias scores did not differ between groups, $t(31)=0.55$, $n s$.

In conclusion, experimentally induced craving (i.e., exposure condition) caused increased distraction by chocolate targets in chocoholics, but not in non-chocoholics, as compared to a nonexposure control condition.

\section{Craving and attentional bias for candy}

To test whether either experimentally induced craving or trait levels of chocolate craving would also be related to an attentional bias for candy, two 2 (Condition: exposure vs. non-exposure) $\times 2$ (Group: chocoholics vs. non-chocoholics) ANOVAs of the attentional bias scores were conducted to investigate both speeded detection and increased distraction effects. These analyses showed that all interaction and main effects were non-significant, all $F$ s $<2.02$, all $p$ 's $>.16$. Taken together, these analyses show that our chocolate attentional bias effects did not generalize to candy.

\section{Correlations}

Pearson correlations were used to examine the relationship between the attentional bias measures (i.e., speeded detection, and increased distraction) and the state chocolate craving measures. To increase power, the measure of state chocolate craving was calculated by taking the mean of the chocolate craving measurements after the first (i.e., craving 2) and the second chocolate exposure (i.e., craving 4). Increased distraction and state chocolate craving were positively correlated, $r=.28, p<.05$. Interestingly, this correlation was significant in the exposure condition, $r=.38$, $p<.05$, and in the chocoholics, $r=.36, p<.05$, but not in the nonexposure condition or in the non-chocoholics, all $r$ 's $<.01$, all $p>$.95. Speeded detection on the other hand was not correlated with state chocolate craving, $r=.001, p=.99$.

\section{Discussion}

It was found that chocoholics who did not receive a chocolate craving induction were faster to detect chocolate targets than neutral targets, relative to non-chocoholics and chocoholics in the exposure condition. Chocoholics who did receive a chocolate craving induction (i.e., exposure condition) were significantly more distracted by chocolate distractors when looking for a neutral target than chocoholics in the non-exposure condition or nonchocoholics in the exposure condition. Interestingly, self-reported 
chocolate craving was positively correlated with increased distraction, in the chocoholics and in the exposure condition, but not in the non-chocoholics and non-exposure condition. Speeded detection, on the other hand, was not correlated with selfreported chocolate craving. Attentional bias effects were specific to chocolate targets; no attentional bias effects were found for candytargets as compared to neutral targets, in none of the groups or conditions.

The present study clearly shows a causal link between chocolate craving and a bias in the distraction component of attention. More specifically, when brought to an elevated state of chocolate craving, chocoholics showed more distraction by chocolate than when they were not brought to this elevated state. This finding sheds more light on the factors that might cause or maintain a food-related attentional bias. In a similar vein, research from the field of addiction, in which heavy drinkers were given a low dose of alcohol, also showed that increased feelings of craving lead to a bias in a similar component, namely maintained attention (e.g., Schoenmakers, Wiers, \& Field, 2008).

Apart from a causal link between chocolate craving and increased distraction, we also found a positive correlation between self-reported levels of state chocolate craving and a bias in increased distraction. These data build on addiction studies that have found larger associations between craving and attentional bias for measures of maintained attention than for measures of initial orienting of attention (Field et al., 2004; Mogg et al., 2005). Adding further to this line of reasoning, in the current study no correlations were found between craving and measures of speeded detection. Theoretical models by Kavanagh, Andrade, and May (2005) and LaBerge (1995) respectively explain this finding by hypothesizing that craving is linked to the extent of rumination on, or greater maintained attention on craving-related stimuli, and that motivational factors are most likely to be evident in maintained attention rather than in the engagement of attention. In the same line, it can be hypothesized that the increased distraction in chocoholics who were assigned to the exposure condition might reflect their motivation to consume chocolate as a result of the experimentally induced craving.

This brings us to the question as to whether a chocolate-related attentional bias in the distraction component might lead to overeating. Previous research has repeatedly shown that restrained eaters as well as bingers tend to overeat as a result of food cravings that were brought about by exposure to cues predicting food intake (e.g., Jansen, 1998). Therefore, it would be of great interest to investigate in future research whether an attentional bias might be the missing link in explaining the relation between food cravings and overeating.

With regard to the chocoholics who were not exposed to chocolates, we found evidence for speeded detection. This finding fits with predictions of the incentive sensitization theory (Robinson \& Berridge, 1993). In this perspective, it can be hypothesized that the bias in speeded detection in this group results from the fact that chocolate cues have acquired incentive salience (i.e., appetitive motivational characteristics) making them more salient and attention-grabbing than other stimuli. Another related explanation as to why trait chocoholics were faster to detect chocolate targets is that this group might exhibit a natural tendency to search for chocolate cues in their environment when they are not in an elevated state of craving. This rationale seems to be supported by the fact that the tendency to search for chocolate cues seems to disappear when craving levels are experimentally increased, as shown by the absence of speeded detection in the chocoholics in the exposure condition. For future research, it would be worthwhile to find out whether the speeded detection of chocolate is also associated with an approach bias.
It is concluded that chocoholics who have been exposed to chocolates show a bias in increased distraction, whereas chocoholics who have not been exposed to chocolates show a bias in speeded detection. Taken together, the present findings further articulate the importance of craving in explaining attentional biases for craving-related stimuli.

\section{Acknowledgements}

This study is part of an ongoing project and is financed by National Research Organization (NWO) Grant 400-04-197, awarded to Anita Jansen. We thank Michelle Bloemen, Annerie Dirkx, Eline Dohmen, Sarah Herbertz, Marieke Jonker, Anique Nieuwendijk, and Nadia Skoropinski for their contribution to the study.

\section{References}

Bauer, D., \& Cox, W. M. (1998). Alcohol-related words are distracting to both alcohol abusers and non-alcohol abusers in the Stroop colour-naming task. Addiction, 93, 1539-1542.

Benton, D., Greenfield, K., \& Morgan, M. (1998). The development of the attitudes to chocolate questionnaire. Personality and Individual Differences, 24, 513-520.

Cooper, M. J., \& Fairburn, C. G. (1992). Selective processing of eating, weight, and shape related words in patients with eating disorders and dieters. British Journal of Clinical Psychology, 31, 363-365.

Cox, W. M., Hogan, L. M., Kristian, M. R., \& Race, J. H. (2002). Alcohol attentional bias as a predictor of alcohol abusers' treatment outcome. Drug Alcohol Dependence, 68, 237-243.

Cox, W. M., Yeates, G. N., \& Regan, C. M. (1999). Effects of alcohol cues on cognitive processing in heavy and light drinkers. Drug Alcohol Dependence, 55, 85-89.

Ehrman, R. N., Robbins, S. J., Bromwell, M. A., Lankford, M. E., Monterrosso, J. R., \& O'Brien, C. P. (2002). Comparing attentional bias to smoking cues in current smokers, former smokers, and non-smokers using a dot-probe task. Drug Alcohol Dependence, 67, 185-191.

Faunce, G. J. (2002). Eating disorders and attentional disorders: A review. Eating Disorders, 10, 125-139.

Field, M., Duka, T., Eastwood, B., Child, R., Santarcangelo, M., \& Gayton, M. (2007). Experimental manipulation of attentional biases in heavy drinkers: do the effects generalize? Psychopharmacology, 192, 593-608.

Field, M., Mogg, K., \& Bradley, B. P. (2005). Craving and cognitive biases for alcohol cues in social drinkers. Alcohol and Alcoholism, 40, 504-510.

Field, M., Mogg, K., Zetteler, J., \& Bradley, B. P. (2004). Attentional biases for alcohol cues in heavy and light social drinkers: the roles of initial orienting and maintained attention. Psychopharmacology, 176, 88-93.

Fox, E., Russo, R., Bowles, R. J., \& Dutton, K. (2001). Do threatening stimuli draw or hold visual attention in sub-clinical anxiety? Journal of Experimental Psychology: General, 130, 681-700.

Francis, J. A., Stewart, S. H., \& Hounsell, S. (1997). Dietary restraint and the selective processing of forbidden and nonforbidden food words. Cognitive Therapy and Research, 21, 633-646.

Franken, I. H. A. (2003). Drug craving and addiction: integrating psychological and neuropsychopharmacological approaches. Progress in Neuro-Psychopharmacology E Biological Psychiatry, 27, 563-579.

Franken, I. H. A., Kroon, L. Y., Wiers, R. W., \& Jansen, A. (2000). Selective cognitive processing of drug cues in heroin dependence. Journal of Psychopharmacology, 14 395-400.

Gross, T. M., Jarvik, M. E., \& Rosenblatt, M. R. (1993). Nicotine abstinence produces context-specific Stroop interference. Psychopharmacology, 110, 333-336.

Hansen, C. H., \& Hansen, R. D. (1988). Finding the face in the crowd: An anger superiority effect. Journal of Personality and Social Psychology, 54, 917-924.

Herman, C. P., \& Polivy, J. (1980). Restrained eating. In A. J. Stunkard (Ed.), Obesity (pp. 208-225). Philadelphia: Saunders.

Jansen, A. (1998). A learning model of binge eating: cue reactivity and cue exposure. Behaviour Research and Therapy, 36, 257-272.

Kavanagh, D. J., Andrade, J., \& May, J. (2005). Imaginary relish and Exquisite torture: The elaborated intrusion theory of desire. Psychological Review, 112, 446-467.

LaBerge, D. (1995). Attentional processing: The brain's art of mindfulness. Cambridge, MA: Harvard University Press.

Lee, M., \& Shafran, R. (2004). Information processing biases in eating disorders. Clinical Psychology Review, 24, 215-238.

Lubman, D. I., Peters, L. A., Mogg, K., Bradley, B. P., \& Deakin, J. F. W. (2000). Attentiona bias for drug cues in opiate dependence. Psychological Medicine, 30, 169-175.

Macleod, C., Mathews, A., \& Tata, P. (1986). Attentional bias in emotional disorders. Journal of Abnormal Psychology, 95, 15-20.

Mathews, A., \& MacLeod, C. (2005). Cognitive vulnerability to emotional disorders. Annual Review of Clinical Psychology, 1, 167-195.

Mogg, K., Bradley, B. P., Hyare, H., \& Lee, S. (1998). Selective attention to food-related stimuli in hunger: Are attentional biases specific to emotional and psychopathological states, or are they also found in normal drive states? Behaviour Research and Therapy, 36, 227-237. 
Mogg, K., Field, M., \& Bradley, B. P. (2005). Attentional and approach biases for smoking cues in smokers: An investigation of competing theoretical views of addiction. Psychopharmacology, 180, 333-341.

Overduin, J., Jansen, A., \& Louwerse, E. (1995). Stroop interference and food intake. International Journal of Eating Disorders, 18, 277-285.

Placanica, J. L., Faunce, G. J., \& Soames Job, R. F. (2002). The effect of fasting on attentional biases for food and body shape/weight words in high and low eating disorder inventory scores. Wiley Periodicals, 32, 79-90.

Rinck, M., Reinicke, A., Ellwart, T., Heuer, K., \& Becker, E. (2005). Speeded detection and increased distraction in fear of spiders: evidence from eye-movements. Journal of Abnormal Psychology, 114, 235-248.

Robinson, T. E., \& Berridge, K. C. (1993). The neural basis of craving: an incentivesensitization theory of addiction. Brain Research Review, 18, 247-291.

Rosse, R. B., Johri, S., Kendrick, K., Hess, A. L., Alim, T. N., Miller, M. M., \& Deutch, S. I. (1997). Preattentive and attentive eye movements during visual scanning of cocaine cue: correlation with intensity of cocaine cravings. Journal of Neuropsychiatry and Clinical Neuroscience, 9, 91-93.

Rosse, R. B., Miller, M. W., Hess, A. L., Alim, T. N., \& Deutch, S. L. (1993). Measures of visual scanning as a predictor of cocaine cravings and urges. Biological Psychiatry, 33, 554-556

Schoenmakers, T., Wiers, R. W., \& Field, M. (2008). Effects of a low dose of alcohol on cognitive biases and craving in heavy drinkers. Psychopharmacology, 197, 169-178. Smeets, E., Roefs, A., van Furth, E., \& Jansen, A. (2008). Attentional bias for body and food in eating disorders: increased distraction, speeded detection, or both? Behaviour Research and Therapy, 46, 229-238.

Stormark, K. M., Laberg, J. C., Nordby, H., \& Hugdahl, K. (2000). Alcoholics' selective attention to alcohol stimuli: automated processing? Journal of Studies on Alcohol and Drugs, 61, 18-23.

Walters, A. J., \& Feyerabend, C. (2000). Determinants and effects of attentional bias in smokers. Psychology of Addictive Behaviours, 14, 111-120. 